\title{
Biological control of late leaf rust disease [Pucciniastrum americanum (Farl.) Arthur] in raspberry (Rubus idaeus L.) using two biological products: Bacillus subtilis (Fungizard ${ }^{\circledR}$ ) and Larrea tridentata botanic extract (CleanCrop®) under screenhouse conditions
}

\author{
Control biológico de la roya tardía de la hoja [Pucciniastrum americanum (Farl.) \\ Arthur] en frambuesa (Rubus idaeus L) a través de dos productos biológicos: Bacillus \\ subtilis (Fungizard®) y extracto botánico de Larrea tridentata (CleanCrop ${ }^{\circledR}$ ) bajo \\ condiciones de malla sombra
}

\author{
Fernando Abel Marín Cortez ${ }^{1}$, Wilberth Chan-Cupul ${ }^{*}$, Marco Tulio Buenrostro Nava ${ }^{1}$, Herminia \\ Alejandra Hernández-Ortega ${ }^{1}$, Gilberto Manzo-Sánchez, Edelmira Galindo Velasco ${ }^{2}$
}

\begin{abstract}
This study aimed to evaluate the suitability of native Trichoderma strains for the biological control of Late Leaf Rust Disease (LLRD) in an organic Rubus idaeus plantation under screenhouse conditions. Four treatments were evaluated: T1) Trichoderma sp. strain Clombta; T2) Trichoderma sp. strain Chlorolota; T3) Co-application of both Trichoderma strains (Clombta + Chlorolota) and T4) Control, which consisted in the application of two biological products: Bacillus subtilis (Fungizard $®$ ) and Larrea tridentata botanic extract (CleanCrop $\left.\left.{ }^{\circledR}\right)\right]$. Disease severity, disease severity index (DSI) and Area Under the Disease Progress Curve (AUDPC) were evaluated. The Co-application of Trichoderma sp. strain Chlorolota and Trichoderma sp. Clombta (from 43,44 to 35,73\%) reduce the LLRD severity at the same level than the Control (from 44,61 to 34,33\%). For DSI, Trichoderma sp. train Chlorolota (64,13) and the Co-application $(61,11)$ showed similar values than those from the Control $(59,84)$. Co-application of both Trichoderma strains showed the lowest AUDPC $(71,2)$, at the same level that the Control $(68,7)$. However, Trichoderma sp. Chlorolota $(72,1)$ achieved the same AUDPC that the Co-application. The use of Trichoderma sp. Chlorolota or its Co-application with Trichoderma sp. strain Clombta was able to reduce the LLRD in $R$. idaeus.
\end{abstract}

Key words: berries, incidence, organic production, foliar application, severity.

\section{RESUMEN}

El objetivo del presente estudio fue evaluar la idoneidad de cepas nativas de Trichoderma para el control biológico de la roya tardía de la hoja (RTH), en una plantación orgánica de Rubus idaeus, bajo condiciones de malla sombra. Se evaluaron cuatro tratamientos: T1) Trichoderma sp. cepa Clombta; T2) Trichoderma sp. cepa Chlorolota; T3) Co-aplicación de ambas cepas de Trichoderma (Clombta + Chlorolota) y T4) Control, el cual consistió en la aplicación de dos productos biológicos: Bacillus subtilis (Fungizard®) y extracto botánico de Larrea tridentata (CleanCrop®)]. Se evaluó la severidad de la enfermedad, el índice de severidad de la enfermedad (IS) y el área bajo la curva de progreso de la enfermedad (ABCPE). La co-aplicación de Trichoderma sp. cepas Chlorolota y Clombta (de 43,44 a 35,73\%) redujo la severidad de RTH al mismo nivel que el Control (de 44,61 a 34,33\%). Para el IS, Trichoderma sp. cepa Chlorolota $(64,13)$ y la Co-aplicación $(61,11)$ mostraron valores similares al Control (59,84). La co-aplicación de ambas cepas de Trichoderma obtuvo el menor ABCPE (71,2), al mismo nivel que el Control (68,7). Sin embargo, Trichoderma sp. Chlorolota (72,1) logró el mismo ABCPE que la Co-aplicación. El uso de Trichoderma sp. Chlorolota o su Co-aplicación con la cepa Clombta fueron capaces de reducir la RTH en R. idaeus.

Palabra clave: frutillas, incidencia, producción orgánica, aplicación foliar, severidad.

1 Facultad de Ciencias Biológicas y Agropecuarias, Universidad de Colima. Tecomán, Colima, México.

2 Facultad de Medicina Veterinaria y Zootecnia, Universidad de Colima. Tecomán, Colima, México.

* Autor de correspondencia: wchan@ucol.mx

Fecha de Recepción: 04 diciembre, 2017.

Fecha de Aceptación: 23 marzo, 2019.

DOI: http://dx.doi.org/10.4067/S0718-34292019005000504. Publicado en línea: 14-junio-2019. 


\section{Introduction}

Red raspberry (Rubus idaeus L.) is cultivated in all continents, mainly North America (U.S.A. and México) and Eastern Europe. The world production is in continuous development, with a world production of $543,421 \mathrm{t}^{\mathrm{t}}$ year-1. Red raspberry and other berries are appreciated by their high sensory value and nutritional compounds, since they are rich in phenolic compounds such as anthocyanins, ellagic acid and vitamin C (Giovanelli et al., 2014).

Red raspberry production around the world is affected by many diseases, including white root rot (Vararia spp.), anthracnose (Elsinoe veneta, Colletotrichum acutatum, Alternaria spp.), spur blight (Didymella applanata), crown gall (Agrobacterium tumefaciens), verticilosis (Verticillium dahliae), gray mold (Botrytis cinerea) and late leaf rust disease (Pucciniastrum americanum) (Pascoe et al., 1984; Shiow et al., 2010; Comeau et al., 2012). This last disease is also called autumn rust, late raspberry rust and yellow late rust. This disease attacking cultivated red and purple raspberries and wild red genotypes (Nelson, 2011).

The main symptoms of leaf disease (LLRD) include small spots, which are initially yellow and turn brown in senescence. Highly susceptible crops are often reduced to leafless canes, where small, light yellow pustules appear on the underside of the infected leaves and light yellow powdery masses damage the fruit and cause early ripening and decay preventing it from being marketed (Nelson, 2011). The principal causal agents are $P$. americanum and Pucciniastrum arcticum (Lagerh.) Tranz.) (RebollarAlviter et al., 2001); according to Converse (1966) both fungus will not cross-infect their respective Rubus host. Pucciniastrum americanum infects canes, leaves, petioles and fruits at all stages of development, this situation that makes this uredinal the principal disease in $R$. idaeus production (Rebollar-Alviter et al., 2001).

The control of LLRD in raspberry cultivation has been carried out by the use of chemical fungicides, principally by cupric molecules, which are costly and pollute the environment, creating risks to human health and affect the quality of the exportable fruit (Masson et al., 2013). Actually, in Mexico the production of $R$. idaeus are in organic systems under screen- and greenhouse condition, this situation makes important the search of biological alternatives to control of LLRD. Several alternatives have been sought to contribute in the control of leaf rust diseases, such as plant extracts, mineral oils (olive, citronella and green tea) and microorganism including bacteria an antagonist fungi (BorgesPereira et al., 2012; Shabana et al., 2017).

The use of Trichoderma sp. to control fungal pathogens in plants is an alternative to explore against LLRD in raspberry plants. Trichoderma species are considerable commercial importance due to their ability to suppress many foliar plants pathogenic fungi such as Botrytis cinerea, Phyllactinia corylea, Cladosporium fulvum, amount others (Sawant, 2014; Prabhakaran et al., 2015). The proposed mechanisms to explain the biocontrol ability of Trichoderma species are antibiosis, cell lysis, competition for nutrients and space, siderophore production and mycoparasitism (Ragi et al., 2013). Therefore, the objective of this present study was to evaluate suitability of native Trichoderma strain for the biological control of late leaf rust disease in $R$. idaeus production under screenhouse conditions.

\section{Materials and Methods}

\section{Fungal source}

Two Trichoderma strains used in the present work were isolated using the soil particle washing technique; strain Trichoderma sp. "Clombta" was isolated from rhizospheric soil of Cucumis melo $\mathrm{L}$. sampled in Armeria, Colima, Mexico (Location: $19^{\circ} 01^{\prime} 26.2 \mathrm{~N}^{\prime \prime}, 103^{\circ} 58^{\prime} 24.1^{\prime \prime} \mathrm{W}$ ); and strain Trichoderma sp. "Chlorolota" was isolated from the rhizosphere of Musa sp. sampled in Coahuayana de Hidalgo, Michoacán, Mexico (Location: $18^{\circ} 26^{\prime} 02.1$ N", $103^{\circ} 04^{\prime} 03.9^{\prime \prime} \mathrm{W}$ ). Both strains was maintained and reactivated in Potato Dextrose Agar (PDA) added with yeast (1\%) and chloramphenicol (100 ppm), under laboratory conditions $\left(25 \pm 1{ }^{\circ} \mathrm{C}, 75 \%\right.$ relative humidity (RH) and 12:12 light: darkness) during the study.

\section{Conidia massive production}

Fungal strains were cultivated under solid state fermentation using rice grains. Previous sterilization the rice grains was washed with purified water three times and hydrated with a solution of chloramphenicol dissolved in methanol and diluted in water at $100 \mathrm{ppm}$. Then, $200 \mathrm{~g}$ of washed rice grains were placed in polyethylene plastic bags 
( $2 \mathrm{~L}$ of capacity) and autoclaved during $45 \mathrm{~min}$ at $120^{\circ} \mathrm{C}$ and 15 psi, autoclaving was repeated three times in intervals of $12 \mathrm{hrs}$. Sterile rice bags were inoculated with $10 \mathrm{~mL}$ of a conidia suspension of Trichoderma strain at a concentration of $1 \times 10^{6}$ conidia $\mathrm{mL}^{-1}$. Inoculated rice bags were deposited in an incubation room at $25{ }^{\circ} \mathrm{C}, 80 \%$ of $\mathrm{RH}$, and $8: 16 \mathrm{~h} \mathrm{~L} / \mathrm{D}$ (artificial white light at $80 \mathrm{~W}$ ). After the incubation time, the conidia were harvested from rice grains by centrifugation. Each rice bag was washed twice with $500 \mathrm{~mL}$ of distilled water with Tween $80^{\circledR}(0.1 \% \mathrm{v} / \mathrm{v})$. Washing liquid and rice were filtered in sieves of 200 and 40 mesh. Filtered liquid (conidia) was centrifuged at $2200 \times g$ for $20 \mathrm{~min}$ and dried in darkness in a Class II Biosafety Cabinet (NU-425, NUAIRE, Minnesota, USA) for five days at $25^{\circ} \mathrm{C}$ (Lezama-Gutiérrez et al., 2012). Harvested conidia were maintained in darkness at 4 ${ }^{\circ} \mathrm{C}$ until utilized in the screenhouse trials.

\section{Foliar Trichoderma application on Rubus idaeus plants under screenhouse conditions}

Trichoderma conidia powder was applied in the mornings (before 7:00 hrs.) to avoid solar radiation, sprays were performed using a backpack sprayer pump (HYD20L-Ecomaqmx ${ }^{\circledR}$, Guadalajara, Jalisco, Mexico), which was calibrated at $1.5 \mathrm{~L} \mathrm{~min}^{-1}$ and $110^{\circ}$ of amplitude. Previous to the application, conidia powder was diluted and mixed in clean water added with soybean oil at $1 \%(\mathrm{v} / \mathrm{v})$ as an organic surfactant, avoiding chemical compounds. Applications were made twice per week (Wednesday and Saturday) during 1,5 months. During that period, a two-sample monitoring session was carried out before the conidia applications. Applications were made during February and March of 2016; in that period, climatic variables such as temperature (Figure 1A and 1B) and relative humidity (Figure 1C) were monitored through a weather station (No. 766560 , situated at latitude: $19,71^{\circ}$, length: $-103,46^{\circ}$ and altitude: $1507 \mathrm{~m}$ ).

\section{Trichoderma Treatments}

Furrows of the experimental plot consisted of a distance of 44,1 $\mathrm{m}$ in length and 2,4 $\mathrm{m}$ of spacing between them, with a distance between plants of $0,5 \mathrm{~m}$ and with 93 plants per furrow. The evaluated treatments were: T1) the application of Trichoderma sp. strain Clombta $\left(1 \times 10^{13}\right.$ conidias ha- $\left.{ }^{-1}\right)$; 2$)$ the application of Trichoderma sp. strain Chlorolota

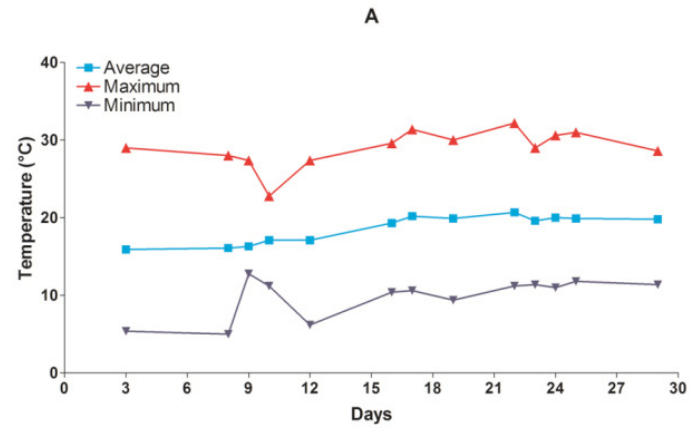

B
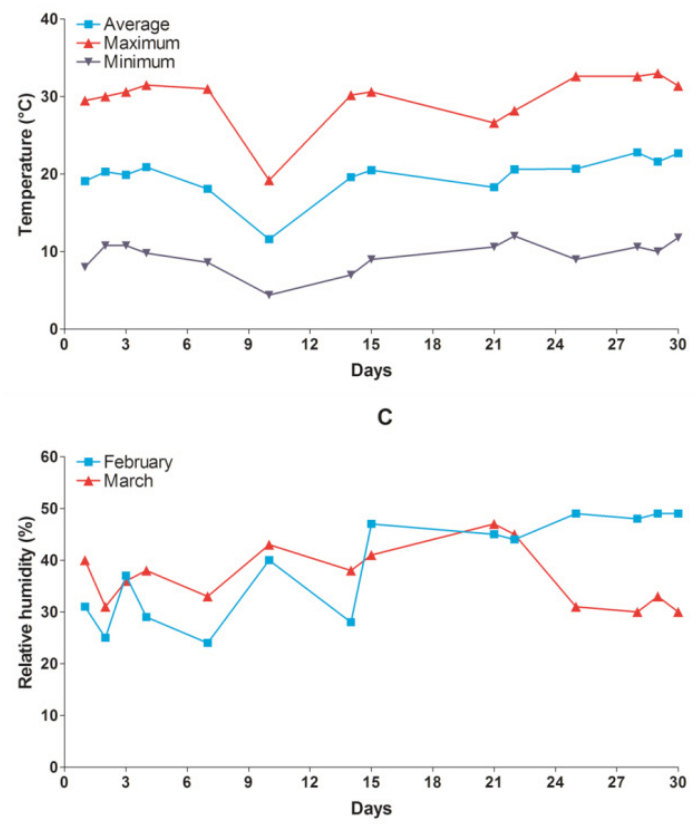

Figure 1. Temperatures in February (A), March (B), and relative humidity $(\mathrm{C})$ values during the experiment.

$\left(1 \times 10^{13}\right.$ conidias ha-1); T3) the application of both Trichoderma strains (Clombta- Chlorolota, referred to as Co-application, at $1 \times 10^{13}$ conidias ha ${ }^{-1}$ ) and T4) Control, which consisted in the application of a mix of three commercial organic products: Bacillus subtilis (Fungizard $囚, 750 \mathrm{~mL} \mathrm{ha}^{-1}$ ) as an organic fungicide, Larrea tridentata as an botanic extract (CleanCrop $\left.{ }^{\circledR}, 500 \mathrm{~mL} \mathrm{ha}^{-1}\right)$ and a natural agricultural adjuvant derived from pine (Eco-Film ${ }^{\circledR}, 100 \mathrm{~mL}$ $\mathrm{ha}^{-1}$ ). This used treatment as a control is the main method used by growers to manage LLRD. The experiment was carried out in an organic plantation; therefore, it was not possible to use a positive control (chemical fungicide) and a negative control (sterile water). 


\section{Development of the diagrammatic scale}

Diagrammatic scales are adequate tools for epidemiology of plantdiseases, theuse of diagrammatic scale reduce the subjectivity of the visual estimation of disease severity, while their use is conventional to be easy and fast for wide range of conditions producing concrete, precise and reproducible results (Angelotti et al., 2008; Michereff et al., 2009). For developing the scale, 25 leaves of $R$. idaeus with different levels of late leaf rust ranging for minimum to maximum severity were collected in an organic orchard from "Berries Paradise S.A.P.I. de C.V." situated in Tuxpan, Jalisco, Mexico (Location: 1953'15” N y 10340'93" W). Leaves with other symptoms were not included in the analysis. Collected leaves were photographed with a digital camera (Sony® Cyber-shot Dsc-w290) at the same distance from the camera lent to the leaves $(25 \mathrm{~cm})$ and the images were used for assessing the percentage of leaf area effected by the late lead rust disease using the software Imagen ${ }^{\circledR}$ (Rasband, 2014). Figure 2 shows the diagrammatic scale with six severity levels ranging from 0 to 50 percentage of damage.

\section{Response variables}

Late leaf rust disease severity was evaluated using the diagrammatic severity scale (Figure 2); an initial evaluation was made before to apply the treatments. The monitoring was made regularly at intervals of four days. The Disease Severity Index (DSI) was calculated using the disease severity data obtained through the diagrammatic severity scale (Figure 2) and the following equation $\mathrm{IS}=[\Sigma(n \times b) /(N \times B)] \times 100$, where $n$ is the severity level, $b$ is frequency of each level, $N$ is the highest level of severity, and $B$ is the total tested plants (Merchán-Gaitán et al., 2014). Finally, the area under the disease progress curve (AUDPC) was calculated, the AUDPC is a useful quantitative summary of disease intensity over time, for comparison across years, locations, or management tactics; therefore, AUDPC was calculated using the equation 1 described by Shaner and Finney (1977), where $Y_{i}$ is the disease level al time $t_{i}$ and $t_{(i+1)} t_{i}$ is the time (days) between two diseases scores.

$$
\mathrm{AUDPC}=\sum_{i=1}^{n}\left[\left(Y_{i+1}+Y_{i}\right)\right]\left[\left(t_{i+1}-t_{i}\right)\right] \text { Equation 1 }
$$

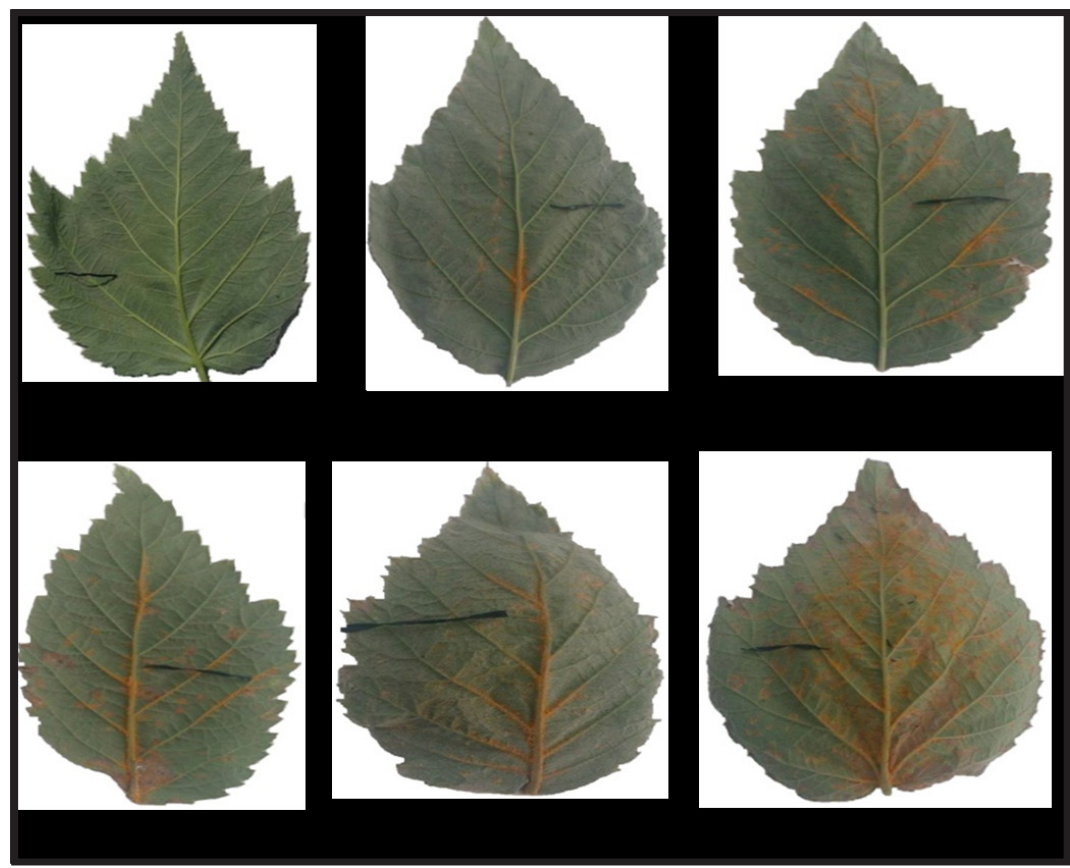

Figure 2. Diagrammatic scale of late leaf rust (Pucciniastrum americanum) in Rubus idaeus showing increasing percentage of affected leaf area-severity. The black line indicates the used scale $(1 \mathrm{~cm})$. 


\section{Experimental design and data analysis}

A randomized complete block design with four treatments and three replicates was established. Each replicate consisted of three plants (experimental unit). The experiment was replicated twice at the same time in two different greenhouses located in the same experimental site. The severity of late leaf rusts, DSI and the AUDPC were analyzed by an analysis of variance and a multiple comparison test using the Least Significant Difference $(\alpha=0.05)$, prior to a homoscedasticity test (Levene test $\alpha=0.05$ ). All tests were performed using StatGraphics Plus software.

\section{Results}

\section{Late leaf rust severity}

Table 1 shows the late leaf rust severity across the evaluation time ( 24 days). In the initial evaluation after the treatments applications, a significant difference ( $F=6.41, P=0.0017)$ in the late leaf rust severity was found between the treatments; application of Trichoderma sp. strain Clombta achieved the highest severity with $49.55 \%$; while the application of Trichoderma sp. strain Chlorolota (46.05\%) and the co-application (43.44\%) of both strains showed the same lowest percentage of severity in comparison to the control (44.61\%). At three days after application of the treatments, the co-application and the control showed the lowest severity with 43.17 and $41.78 \%$, respectively, while the single Trichoderma strains achieved the highest severity (Trichoderma sp. strain Clombta $=49.55 \%$ and Trichoderma sp. strain Chlorolota $=46.05 \%$ ).

During the evaluations at 7, 10, 14 and 17 days, a significant difference between treatments was found. In these evaluations the lowest severity was found in the control and in the treatments: Trichoderma sp. strain Chlorolota and the co-application; in the control the severity ranged from $39.83 \%$ (7 days) to $44.77 \%$ (10 days), while in Trichoderma sp. strain Chlorolota and the co-application the severity ranged from $41.39 \%$ (7 days) to $46.16 \%$ (10 days) and from $41.44 \%$ (7 days) to $46.44 \%$ (10 days), respectively. By other hand, the treatment Trichoderma sp. strain Clombta achieved the highest severity, which ranged between 46.67 (17 days) and $49.00 \%$ (14 days). However, in the last two evaluations at $21(F=16,29, P=0.00001)$ and 24 days $(F=11.26, P=0.00001)$, the co-application and the control showed the lowest severity percentage of late leaf rust disease. At 21 days the co-application and the control achieved 38.61 and $38.39 \%$ of severity, respectively; while at the end of evaluation (24 days), the co-application and the control obtained 35.72 and $34.33 \%$ of severity. Regarding to the blocks of the experimental design, there were not found significant differences $(P>0.05)$ during the first $17^{\text {th }}$ days. However, in the last evaluation ( 21 days, $P=0.00001$ and 24 days, $P=0.00001$ ) the blocks showed significant differences, this differences could be attributed to the microclimate under the screenhouse conditions.

Table 1. Late leaf rust (Pucciniastrum americanum) severity (\%) in Rubus idaeus under the application of Trichoderma strains.

\begin{tabular}{|c|c|c|c|c|c|c|c|c|}
\hline \multirow[b]{2}{*}{ Treatments } & \multicolumn{8}{|c|}{ Evaluation period (days) } \\
\hline & 1 & 3 & 7 & 10 & 14 & 17 & 21 & 24 \\
\hline Tri. sp. Clombta (T1) & $49.55 \mathrm{a}$ & $48.33 \mathrm{a}$ & $47.44 \mathrm{a}$ & $48.94 \mathrm{a}$ & $49.00 \mathrm{a}$ & $46.67 \mathrm{a}$ & $46.28 \mathrm{a}$ & $42.67 \mathrm{a}$ \\
\hline Tri. sp. Chlorolota (T2) & $46.05 \mathrm{~b}$ & $45.22 \mathrm{ab}$ & $41.39 \mathrm{~b}$ & $46.16 \mathrm{~b}$ & $43.83 \mathrm{~b}$ & $41.83 \mathrm{~b}$ & $43.55 \mathrm{a}$ & $39.78 \mathrm{a}$ \\
\hline Co-application (T3) & $43.44 \mathrm{~b}$ & $43.17 \mathrm{~b}$ & $41.44 \mathrm{~b}$ & $46.44 \mathrm{~b}$ & $44.11 \mathrm{~b}$ & $41.72 \mathrm{~b}$ & $38.61 \mathrm{~b}$ & $35.72 \mathrm{~b}$ \\
\hline Control (T4) & $44.61 \mathrm{~b}$ & $41.78 \mathrm{~b}$ & $39.83 \mathrm{~b}$ & $44.77 \mathrm{~b}$ & $42.27 \mathrm{~b}$ & $40.05 \mathrm{~b}$ & $38.39 \mathrm{~b}$ & $34.33 \mathrm{~b}$ \\
\hline$F$-test & 6.41 & 5.54 & 6.33 & 4.06 & 8.10 & 13.87 & 16.29 & 11.26 \\
\hline$P$-value & 0.0017 & 0.0038 & 0.0019 & 0.0156 & 0.0004 & 0.00001 & 0.00001 & 0.00001 \\
\hline \multicolumn{9}{|l|}{ Blocks } \\
\hline B1 & 45.20 & 43.79 & 40.79 & 46.33 & 44.33 & 41.87 & $44.16 \mathrm{a}$ & $40.75 \mathrm{a}$ \\
\hline B2 & 45.37 & 44.79 & 4.20 & 46.16 & 44.45 & 42.16 & $40.08 \mathrm{~b}$ & $36.58 \mathrm{~b}$ \\
\hline B3 & 47.17 & 45.29 & 43.58 & 47.25 & 45.62 & 43.67 & $40.87 \mathrm{~b}$ & $37.04 \mathrm{~b}$ \\
\hline$F$-test & 1.43 & 0.53 & 1.71 & 0.61 & 0.65 & 2.10 & 6.81 & 5.40 \\
\hline$P$-value & 0.2540 & 0.5932 & 0.1974 & 0.5492 & 0.5306 & 0.1396 & 0.0037 & 0.0099 \\
\hline
\end{tabular}

Disease severity index values in each column with different letters are significantly different from each another (DMS, $\alpha=0.05, n=3)$. 


\section{Disease severity index}

There were significant differences in the DSI of the late leaf rust during the evaluation time. In the first three evaluations, the application of Trichoderma strain Clombta did not reduce the DSI in the treated plants and achieved the highest values with 80.42 $(F=6.02, P=0.0025), 81.11 \quad(F=10.85, P=0.00001)$ and $81.98(F=23.13, P=0.00001)$ at 1,3 and 7 days, respectively (Figure 3 ). While Trichoderma strain Chlorolota (DSI ranged from 75.45 to 71.74 ), the coapplication (DSI ranged from 73.49 to 72.77 ) and the control (DSI ranged from 71.64 to 70.00 ) reduced in a few amount the DSI, achieving significantly the lowest values in comparison to Trichoderma strain Clombta (Figure 3). At the fourth evaluation (10 days) a slight increase of the DSI in the treatments Trichoderma strain Clombta, co-application and the control was found, when was compared with the firts evaluation; while Trichoderma sp. strain Chlorolota maintained its DSI. This behavior may be related with the decrease of the maximum temperature and the increase of the minimum temperature in the evaluation period $\left(9^{\text {th }}\right.$ and $10^{\text {th }}$ of February, Figure 1A), in addition, could be related to the increase of the relative humidity at the same date (Figure 1C).

During the $5^{\text {th }}$ (14 days) and $6^{\text {th }}$ (17 days) evaluation (Figure 3), the treatments co-application (14 days=70.05 and 17 days=68.13) and the control
(14 days $=68.51$ and days $=67.10)$ achieved the lowest DSI [14 days: $F=41.30, P=0.00001$ and 17 days: $F=42.53, P=0.00001)$. However, Trichoderma sp. strain Chlorolota ( 14 days $=72.32$ and days $=70.04)$ statistically showed the same DSI in comparison to the co-application. By other hand, Trichoderma sp. strain Clombta achieved the highest values (14 days $=81.75$ and 17 days $=79.28$ ). At the penultimate evaluation (21 days), the treatments Trichoderma sp. strain Chlorolota (68.14) and the co-application (66.19) achieved statistically $(F=15.29, P=0.00001)$ the same DSI in comparison to the control (63.96); however, the Trichoderma sp. strain Clombta obtained the highest value (77.72). Finally, in the evaluation at 24 days, the highest $(F=13.35$, $P=0.00001)$ DSI was found in the treatment of Trichoderma sp. strain Clombta (76.03) as happened throughout the experiment; while the treatments Trichoderma sp. strain Chlorolota, co-application and control achieved low values of DSI with 64.13, 61.11 and 59.84 respectively (Figure 3 ). Regarding to the blocks of the experimental design, only two evaluations were found to be significantly different (21 days: $F=6.81, P=0.0037$ and 24 days: $F=5.40$, $P=0.0099$ ). These differences could be attributed to other environmental variables (intensity of light, evapotranspiration, humidity and other facts in to the screenhouse etc.) that were no taken into consideration for the present study.

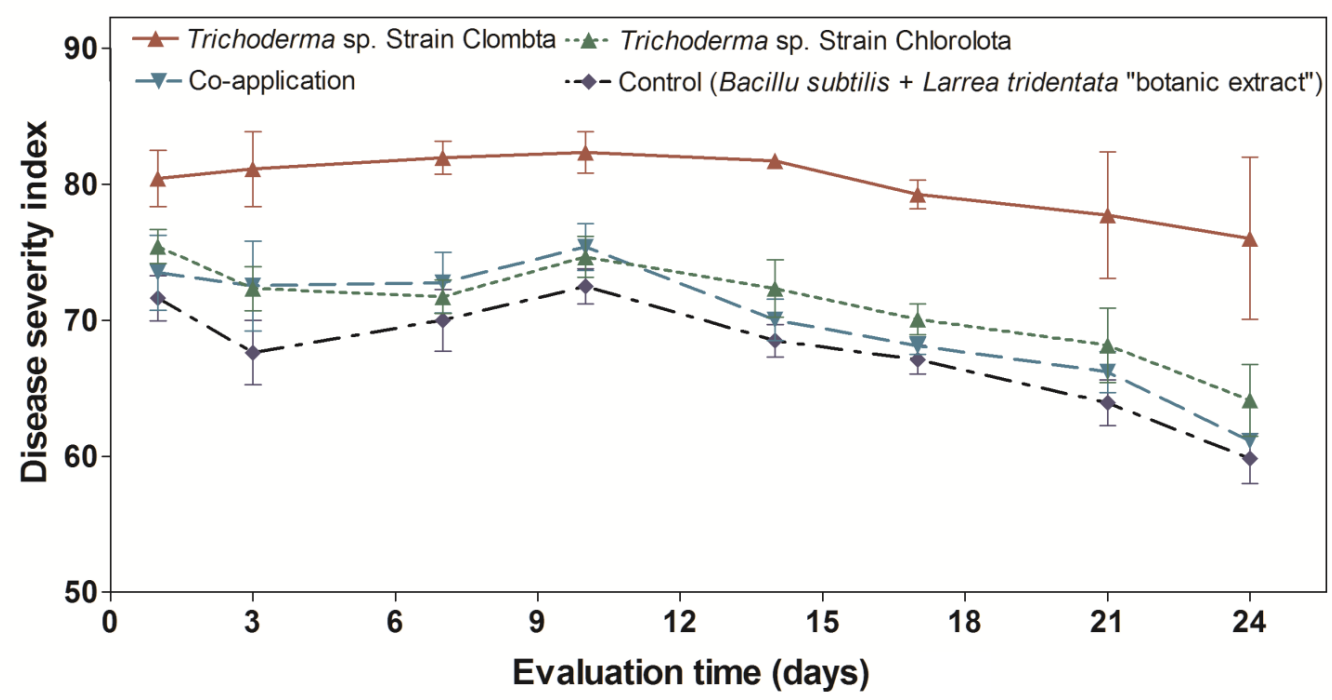

Figure 3. Disease severity index of late leaf rust in Rubus idaeus under the application of Trichorderma strains as biological control. Each point represents the average $( \pm$ SEM) of at least three replications. 


\section{Area under the disease progress curve}

The AUDPC was estimated with a trapezoidal method (equation 1), which discretize the time variable and calculate de mean disease intensity between ach pair of adjacent time points. The result indicates that the control (a mix of Bacillus subtilis and Larrea tridentata "botanic extract") achieved the lowest AUDPC with 68.7 (Figure 4); however, this value was statistically equal to the co-application of both strains (Clombta and Chlorolota) of Trichoderma sp. with a value of 71.2. The application of Trichoderma sp. strain Chlorolota (72.1) achieved statistically the same AUDPC with the co-application treatment, but it was different to the control. Otherwise, the application of Trichoderma sp. strain Clombta achieved the highest AUDPC value $(F=26.87$, $P=0.00001$ ) with 80,6 .

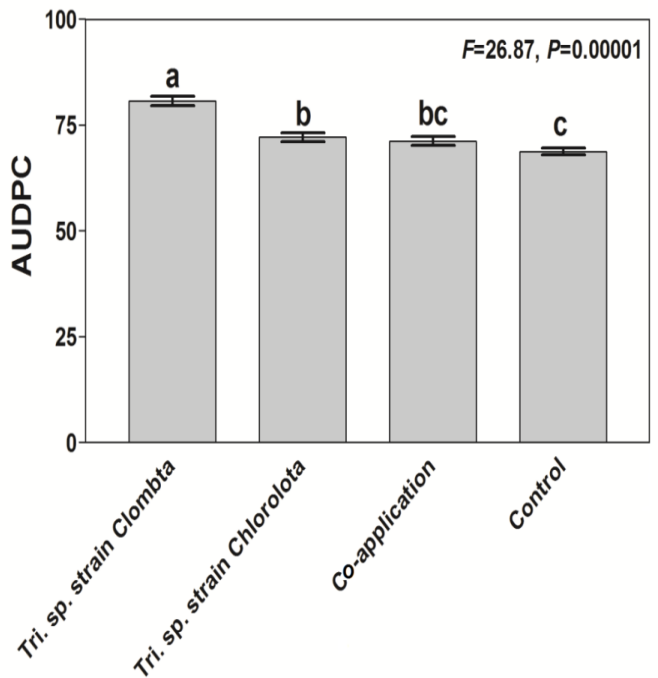

Figure 4. The total area under the disease progress curve (AUDPC) of late leaf rust (Pucciniastrum americanum) in Rubus idaeus under the application of Trichoderma strains as biological control. Means ( \pm standard error) with different letters are different letters are significantly different from each another (MSD, $\alpha=0.05, n=3$ ).

\section{Discussion}

Late leaf rust disease is one the most important plant disease in the organic and conventional production of raspberry under greenhouse condition. There is little information about this disease in $R$. idaeus production, according to RebollarAlviter et al. (2001); the causal agent of LLRD on $R$. idaeus in Mexican production is Pucciniastrum americanum. The epidemiology of LLRD was described by Rebollar-Alviter et al. (2003), the authors suggested that the severity of LLRD is different according to the plant strata; basal (10-55\%) and middle (2-60\%) strata are more prone to the rust. Although in this study did not evaluate the severity by strata, the severities found were less than $50 \%$ in all treatments, this can be due to the effect of the application of biological products (Trichoderma sp.).

In non-organic plantations of raspberry, the control of LLRD is based only in the application of chemical fungicides, in a previous study, RebollarAlviter et al. (2003) reported severities of LLRD in raspberry with values less than $20 \%$, unlike of this study, the authors evaluated chemical fungicides to control LLRD; treatments with lower $(<5.0 \%)$ severity were: Tebuconazole-copper, Triadimefon-anilazine and paraffinic oil, the latter is considered an agroecological insecticide; however, it is a byproduct of petroleum distillation. These severities values reported by Rebollar-Alviter et al. (2003) are low if we compared with that obtained in this study with the application of Trichoderma sp. strains. In addition, Rebollar-Alviter et al. (2003) reported less cumulative incidence for Triadimefonanilazine $(<140 \%)$ and for paraffin oil $(<150 \%)$. We cannot make comparisons with the results of the present study, because different methodologies were used to determine the severity indexes.

For biological control of LLRD in others economic important crops is based principally in the use of botanic extracts; recently, Shabana et al. (2016) reported the inhibition of spore germination of Puccinia triticina, causal agent of the lead rust disease in wheat, by the effect of plant extracts such as garlic (93.71\%), clove (98.86\%), white cedar (97.76\%) Brazilian pepper (97.12\%), neem (98.99\%) among other extracts. In addition, the efficacy of plant extract on the leaf rust severity were evaluated, a substantial efficacy of $40.41 \%$ was found, when it was applied white cedar (Shabana et al., 2017). In other study, Reiss and Jorgensen (2016) reported that the Bacillus subtillis strain QST713 is effective to reduce the severity of the yellow rust (Puccinia striiformis $\mathrm{f}$. sp. tritici) in wheat, providing up to $60 \%$ of control.

Regarding to the AUDPC, Rebollar-Alviter et al. (2001) reported a higher value in three different strata of the raspberry plant, values were 121.81 , 131.07 and 94.3 for the basal, medium and high strata, respectively, it should be mentioned that in such study, no control methods were evaluated, it was only the 
epidemiological description of rust. In another study, Rebollar-Alviter et al. (2003) reported an adjusted AUDPC, the values were lower than those of the present study (between 2,8 and 19,51), and this is due to the evaluated products, which were chemical fungicides such as Tebuconazol-copper $(2,85)$ and the paraffin oil $(3,29)$. More recently, Reiss and Jorgensen (2016) reported that the application of $B$. subtilis (Serenade $\AA, 2 \mathrm{~L} \mathrm{ha}^{-1}$ ) reduce the AUDPC at the same level that the application of prothioconazole ( $200 \mathrm{~g}$ of i. a. ha-1), with values of 550 and 150 approximately.

In other phytopathogens and crops, the effectiveness of Trichoderma sp. to reduce SI and severity of plant diseases is well known. In this sense Yao et al. (2016) reported that Trichoderma sp. strain HNA14 reduces the SI of the late blight of the potato (Phytophthora infestans), in addition to increasing the fresh and dry weight of the plants.

The foliar application (phyllosphere and the fructosphere) of Trichoderma is exposed to the harsh gaseous atmosphere and faces sharp fluctuations in temperature and moist on leaf surface, vapor water pressure deficit, gases, air pollutants, wind, radiation, etc. These factors make the foliar environment very different from the soil environment and the epiphytic microbial populations differ substantially from the rhizosphere populations (Sawant, 2014). The spores of Trichoderma in the phyllosphere competes principally with bacteria and yeasts, these populations keep changing as a result of fluctuations in the physical, chemical and nutritional environment of the phyllosphere (Sylla et al., 2013). However, the effectiveness of Trichoderma to reduce foliar plant pathogens has been demonstrated, i. e. Co-application of Trichoderma harzianum and Trichoderma viride was able to reduce severity damage of head blight (head scab) in wheat, when the AUDPC were 305,7 in the Trichoderma Co-application, while in the control (unsprayed plants) were 1047,5 (Panwar et al., 2014). This study sets the background for future related works in order to test the studied Trichoderma strains (Clombta and Chlorolota), as well as to elaborate and evaluate the formulated products (liquids or wettable powders) of these native strains.

\section{Conclusion}

The co-application of two native Trichoderma strains (Clombta and Chlorolota) reduced the severity of the LLRD in R: idaeus at the same level that the application of two biological commercial products (Control: Fungizard $\AA=$ B. subtilis and CleanCrop ${ }^{\circledR}=L$. tridentata botanic extract). Trichoderma sp. Chlorolota and its co-application with Trichoderma sp. Clombta were able to reduce the severity index of LLRD at the same level that the Control. The Co-application of the two native Trichoderma strains and the Control achieved significantly the same and the lowest AUDPC of LLRD in R. idaeus. The foliar application of Trichoderma sp. Chlorolota or its coapplication with Trichoderma sp. Clombta is an alternative to management of LLRD in the organic production of raspberry in screenhouse condition.

\section{Literature Cited}

Angelotti, F.; Scapin, C.R.; Tessmann, D.J.; Vida, J.B.; Oliveira, R.R.; Canteri, M. G.

2008. Diagrammatic scales for assessment of grapevine rust. Tropical Plant Pathology, 33 (6): 439-443.

Borges-Pereira, R.; Ciavareli-Lucas, G.; Perina, F.J.; Alves, E. 2012. Essential oils for rust control on coffee plants. Ciência e Agrotecnologia Lavbras, 36 (1): 16-24.

Comeau, C.; Jean-Pierre, P.; Moreau, G.

2012. Beneficial impacts of the combined use of rain shelters and reflective groundcovers in an organic raspberry cropping system. Agriculture Ecosystem \& Environment, 155 (1): 117-123.

Converse, R.H.

1966. Diseases of raspberries and erect and trailing blackberries. Agricultural Research Service, U.S. Dept. of Agriculture, Washington, D. C. U. S. A. 112 pp.

Giovanelli, G.; Limbo, S.; Buratti, S.

2014. Effect of new packaging solutions on physic-chemical, nutritional and aromatic characteristics of red raspberries (Rubus idaeus L.). Postharvest Biology and Technology, 98 (1): 72-81.
Lezama-Gutiérrez, R.; Molina-Ochoa, J.; Chávez-Flores, O.; Ángel-Sahagún, C.A.; Skoda, S. R.; Reyes-Martínez, G.; Barba-Reynoso, M.; Rebolledo-Domínguez, O.; Ruíz-Aguilar, G. M. L.; Foster, J. E.

2012. Use of the entomopathogenic fungi Metarhizium anisopliae, Cordyceps bassiana and Isaria fumosorosea to control Diaphorina citri (Hemiptera: Psyllidae) in Persian under field conditions. International Journal of Tropical Insect Science, 32 (1): 39-44.

Masson, V. M.; Moraes, W. B.; Furtado, E. L.

2013. Chemical control of Eucalyptus rust: Brazilian experiences. In: M. Nita (Edit.) Fungicides-Showcases of integrated plant disease management from around the world. Rijeka, Croatia, Intech Open. 118-134 pp.

Merchán-Gaitán, J.B.; Ferrucho, R. L.; Álvarez-Herrera, J. G. 2014. Efecto de dos cepas de Trichoderma en el control de Botrytis cinérea y la calidad de fruto en fresa (Fragaria sp.). Revista Colombiana de Ciencias Hortícolas, 8 (1): 44-56. 
Michereff, S.J.; Noronha, M.A.; Lima, G.S.A.; Albert, I.C.L.; Melo, E.A.; Gusmao, L.O.

2009. Diagrammatic scale to asses downy mildew severity in melon. Horticultura Brasileira, 27 (1): 76-79.

Nelson, S.

2011. Raspberry late leaf rust in Hawaii caused by Pucciniastrum americanum. Plant Disease, U. S. Department of Agriculture, Manoa, Hawaii, Plant Disease Series, 5 pp. www.ctahr.hawaii.edu/freepubs.

Panwar, V.; Aggarwal, A.; Singh, G.; Verma, A.; Sharma, I.;

Saharan, M.S.

2014. Efficacy of foliar spray of Trichoderma isolates against Fusarium graminearum causing head blight (head scab) of wheat. Journal of Wheat Research, 6 (1): 1-5.

Pascoe, I.G., Washington, W.S.; Guy, G.

1984. White root rot of raspberry in Victoria is caused by a Vararia species. The British Mycological Society, 82 (4): 723-726.

Prabhakaran, N.; Prameeladevi, T.; Sathiyabama, M. \& Kamil, D. 2015. Screening of different Trichoderma species against agriculturally important foliar plant pathogens. Journal of Environmental Biology, 36 (1):191-198.

Ragi, P.R.; Sivan, V.V.; Jhon, J.; Sujana, K.A. \& Kumar, N.A. 2013. Management of leaf rust disease of medical plant Justicia gendarussa Burnm. F. with antagonism fungi (Trichoderma harzianum). Journal of Horticultural Science and Ornamental Plants, 5 (2): 68-70.

Rasband, W.S.

2014. ImageJ, V. S. National Institutes of Health, Bethesda, Maryland USA, http://ImageJ.nih.gob/IJ/.

Rebollar-Alviter A.; Mora-Aguilera, G., Leyva-Mir, G.

2003. Progreso temporal y control de la roya [Pucciniastrum americanum (Farl.) Arth.] de la frambuesa roja (Rubus idaeus L.) en valle de Bravo, México. Revista Mexicana de Fitopatología, 21 (3): 278-284.
Rebollar-Alviter, A.; Leyva-Mir, S.G.; Mora-Aguilera, G.; Valdovinos-Ponce, G.; Romero-Ceva, S.

2001. Identificación y biología del agente causal de la roya roja (Rubus idaeus L.) en México. Revista Mexicana de Fitopatología, 19 (2):168-174.

Reiss, A.; Jorgensen, L. N.

2017. Biological control of yellow rust of wheat (Puccinia striiformis) with Serenade®ASO (Bacillus subtilis strain QST713. Crop Protection, 93 (1):1-8.

Sawant, I.

2014. Trichoderma-foliar pathogenic interactions. The open Mycology Journal, 8 (1): 58-70.

Shabana, Y.M.; Abdalla, M.E.; Shahin, A.A.; El-Sawy, M.M.; Draz, I.S. \& Youssif, A.W.

2017. Efficacy of plant extracts in controlling wheat leaf rust disease caused by Puccinia triticina. Egypt Journal of Basic and Applied Sciences, 4 (1):67-73.

Shaner, G.; Finney, R. A.

1977. The effect of nitrogen fertilization on the expression of slow-mildewing resistance in Knox wheat. Phytopathology, 6 (1): 1051-1056.

Shiow, Y.W.; Chi-Tsun, C.; Jun-Jie, Y.

2010. Effect of allyl isothiocyanate on antioxidants and fruit decay of blueberries. Food Chemistry, 120 (1): 199-204.

Sylla, J.; Alsanius, B.W.; Krüger, E.; Reineke, A.; Strohmeier,

S.; Wohanka, W.

2013. Leaf microbiota of strawberries as affected by biological control agents. Phytopathology, 103 (10): 1001-1011.

Yao, Y.; Li, Y.; Chen, Z.; Zheng, B.; Zhang, L.; Niu, N.; Meng, J.; Li, A.; Zhang, J.; Wang, Q.

2016. Biological control of potato late blight using isolates of Trichoderma. American Journal of Potato Research, 93 (1): 33-42. 
